\title{
Once a man tests, the partner tests as well. A comparison by gender for HCT and STD clinic attendance
}

\author{
Maria Nambira*, Lydia Mwolobi \\ From 17th International Symposium on HIV and Emerging Infectious Diseases (ISHEID) \\ Marseille, France. 23-25 May 2012
}

\section{Introduction}

Since its outbreak in 1986, Uganda has registered a tremendous decline in HIV prevalence rates from $15 \%$ in 1991 to 5\% in 2002 though up again to 6.4\% in 2006 (2006 UDHS). Currently, an estimated 100,000 new HIV infections occur annually. In recent years, the uptake and practice of preventive behavior have declined, particularly among men. Currently, almost 40 \%t of people with HIV are not diagnosed until they already have developed AIDS. That can be up to 10 years after they first became infected with HIV. Finding out whether a person is infected with HIV is the first step to improving their health and that of their partners and their families. The study aimed to assess the contribution, role of men in the fight of HIV/AIDS through HCT.

\section{Methods}

The project monitored all individuals attending STD and ART clinics. The project sought to check whether when requested, males brought their female counterparts for testing and vice versa during the September 2010 to Sept 2011 at Luwero health centre IV in Luwero district, Uganda. Clinical data was used.

\section{Results}

In the reporting period, we estimated that 1,230 people were attending ART clinics and about 3,200 people attending STD clinics. More males once tested brought more spouses for testing. The numbers were much less vice versa. For every 1 man tested at least 3 women were tested. This was also recorded in polygamous relationships. Clinic Type Males Females Total Attendants

\footnotetext{
* Correspondence: nuela.maria@gmail.com

Monitoring and Evaluation Specialist at African Medical and Research Foundation, Kampala, Uganda
}

(c) 2012 Nambira and Mwolobi; licensee BioMed Central Ltd. This is an Open Access article distributed under the terms of the Creative Commons Attribution License (http://creativecommons.org/licenses/by/2.0), which permits unrestricted use, distribution, and reproduction in any medium, provided the original work is properly cited.
Cite this article as: Nambira and Mwolobi: Once a man tests, the partner tests as well. A comparison by gender for HCT and STD clinic attendance. Retrovirology 2012 9(Suppl 1):P113.

Submit your next manuscript to BioMed Central and take full advantage of:

- Convenient online submission

- Thorough peer review

- No space constraints or color figure charges

- Immediate publication on acceptance

- Inclusion in PubMed, CAS, Scopus and Google Scholar

- Research which is freely available for redistribution 